\title{
Receptor-Mediated Uptake of Acid $\alpha$-Glucosidase Corrects Lysosomal Glycogen Storage in Cultured Skeletal Muscle
}

\author{
ANS T. VAN DER PLOEG, M. CHRISTA B. LOONEN, PIET A. BOLHUIS, \\ HERMAN M. F. BUSCH, ARNOLD J. J. REUSER, AND HANS GALJAARD \\ Department of Cell Biology and Genetics [A.T.V.D.P., A.J.J.R., H.G.], Department of Neurology, Erasmus \\ University, Rotterdam, and Department of Neurology, Academic Medical Center, Amsterdam, \\ The Netherlands [P.A.B.]
}

\begin{abstract}
Attempts at treatment of glycogenosis type II and other lysosomal storage disorders by enzyme replacement have been reported. Parenteral enzyme administration has been ineffectual. Treatment by bone marrow transplantation is currently under investigation. We have used cultured skeletal muscle cells from a patient with infantile glycogenosis type II to study fundamental aspects of enzyme replacement therapy. Efficient uptake of acid $\alpha$ glucosidase was achieved by using the mannose-6-phosphate receptor on the cell surface as a target for an enzyme precursor with phosphorylated high-mannose types carbohydrate chains purified from human urine. We found that the enzyme was channeled to the lysosomes and converted to mature acid $\alpha$-glucosidase. Glycogen storage was reversed. The results are discussed in relation to treatment of glycogenosis type II. (Pediatr Res 24: 90-94, 1988)
\end{abstract}

\section{Abbreviation}

IGF, insulin-like growth factor

Pompe's disease or glycogenosis type II is an autosomal recessive disorder $(1,2)$. Deficiency of acid $\alpha$-glucosidase is the primary defect, leading to lysosomal accumulation of glycogen (3). Cardiomegaly, hypotonia, and moderate hepatomegaly are characteristic of the rapidly progressive infantile form of the disease. Death occurs in the first or second year of life as a result of cardiorespiratory failure (4). In late onset forms of the disease (juvenile and adult variants) impairment of skeletal muscle function is usually the only symptom (5). Patients more than $60 \mathrm{yr}$ old have been described (6).

In the past, enzyme replacement has been attempted in various Iysosomal storage disorders by parenteral administration of purified lysosomal enzymes $(7,8)$. Infantile Pompe patients received acid $\alpha$-glucosidase purified from Aspergillus niger $(9,10)$ or human placenta (4). None of these attempts was clinically successful. At present, this form of therapy has been abandoned, and treatment of lysosomal storage disorders by bone marrow transplantation is currently under investigation (11-16). Some beneficial effects have been reported in the mucopolysacchari-

Received July 27, 1987; accepted March 3, 1988

Correspondence A. T. Van Der Ploeg, M.D., Department of Cell Biology and Genetics, Erasmus University, P.O. Box 1738, 3000 DR Rotterdam, The Netherlands.

Supported by a grant from the Princess Beatrix Fund. doses. However, the few attempts at treatment of glycogenosis type II with bone marrow transplantation have not been successful $(15,16)$. No increase of acid $\alpha$-glucosidase activity was found in muscle tissue. Elevated enzyme levels were only measured in blood cells, which in fact reflected the presence of donor cells.

The lack of an efficient treatment for lysosomal storage diseases in general and glycogenosis type II in particular has stimulated us to investigate fundamental aspects of receptor-mediated enzyme replacement therapy.

During the last decade much has been learned about the role of receptors as signal transducers, and as mediators of selective transport of macromolecular compounds. The mannose-6-phosphate receptor was recognized by its function in endocytosis of high-uptake forms of lysosomal enzymes in cultured fibroblasts $(17,18)$. Later it became evident that the receptor is predominantly localized intracellularly, and is mainly involved in selective transport of lysosomal enzymes from the Golgi complex to lysosomes (19). Various cell types appear to contain the receptor (20), but a systematic study of the expression of the mannose-6phosphate receptor on the plasma membrane of different cell types has not been performed.

In a previous study, we have shown that mannose-6-phosphate receptors are present at the cell surface of myotubes and mediate efficient uptake of lysosomal enzymes containing carbohydrate chains with mannose-6-phosphate residues (21). However, the most important question remained unanswered: does exogenously supplied enzyme reach the glycogen storage vacuoles of skeletal muscle cells and does it degrade the accumulated glycogen. To answer this question cultured skeletal muscle cells from an infantile glycogenosis type II patient were used as a model system, and supplied with a high-uptake precursor of acid $\alpha$ glucosidase purified from human urine.

\section{METHODS}

Cell culture procedures. Muscle cell cultures were obtained from an infantile glycogenosis type II patient by dissociation of a biopsy from the quadriceps muscle $(0.1 \mathrm{~g}$ wet weight, Fig. 1) as described by Yasin et al. (22). Primary cultures were preplated once to select against fibroblasts (23). Dulbecco's modification of Eagle's medium supplemented with fetal calf serum $(20 \%)$, chicken embryo extract ( $2 \%$ ), and antibiotics were used as growth medium. An atmosphere of $10 \% \mathrm{CO}_{2}$ and $90 \%$ air was maintained. Experiments were performed in 24-well plastic tissue culture plates. At a density of $10^{4}$ cells $/ \mathrm{cm}^{2}$ myoblast fusion was stimulated by a change of medium. The fusion medium consisted of Dulbecco's modification of Eagle's medium supplemented with horse serum (2\%), in an atmosphere of $5 \% \mathrm{CO}_{2}$ and $95 \%$ air. In the next 4 days more than $90 \%$ of the mononuclear cells fused to form myotubes. 


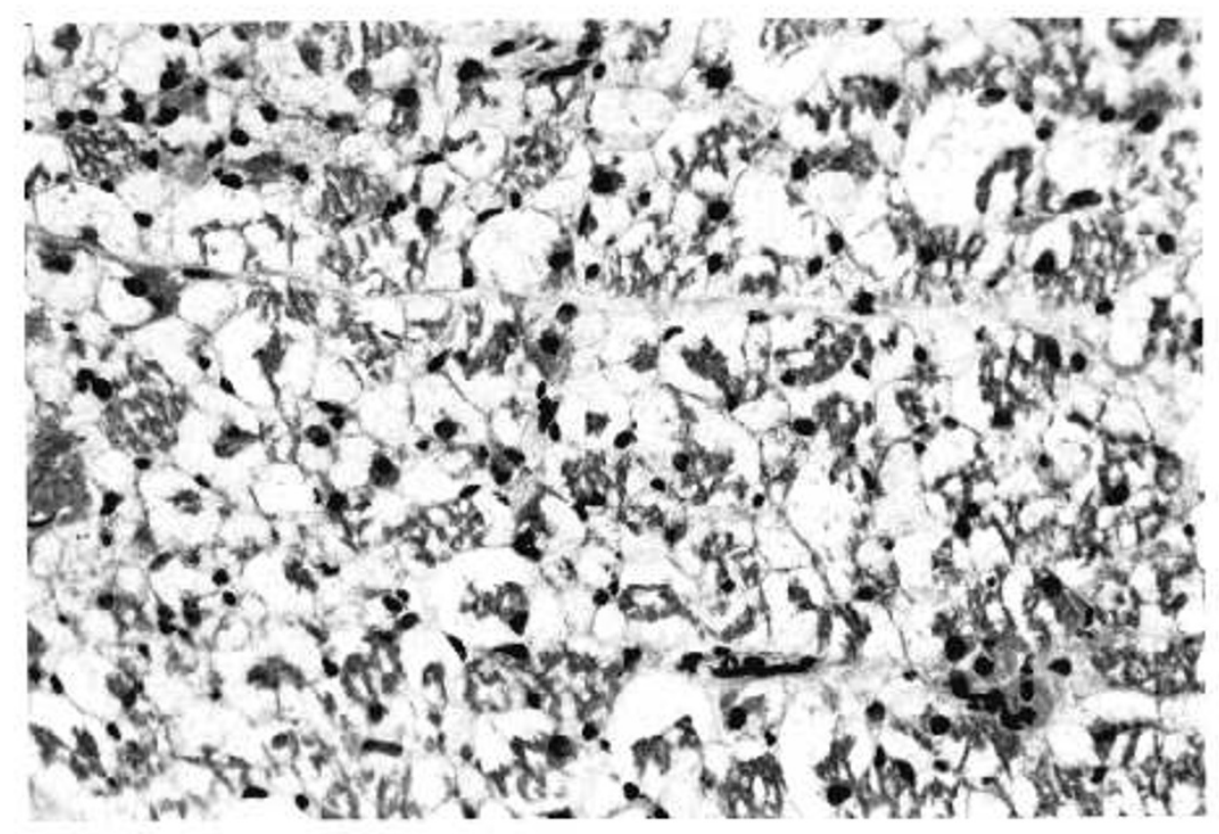

Fig. 1. Light micrograph of muscle tissue derived from the severely damaged quadriceps of the patient at 9 months of age (hematoxylin and eosin, $\times 630$ ).

A high-uptake $110 \mathrm{kDa}$ precursor of acid $\alpha$-glucosidase (sp. act. $180.2 \mu \mathrm{mol} 4$-methylumbelliferone $/ \mathrm{mg}$ protein $/ \mathrm{h}$ ) was purified from human urine as described by Oude Elferink et al. (24). Myotubes were incubated with enzyme in a final concentration of $1 \mu \mathrm{mol} \mathrm{4-methylumbelliferone} / 500 \mu \mathrm{l} / \mathrm{h}$ during $16 \mathrm{~h}$ as described previously (21).

Miscellaneous. Acid $\alpha$-glucosidase activity was measured with the artificial substrate 4-methylumbelliferyl- $\alpha$-D-glucopyranoside or with glycogen $(25,26)$. Glycogen content of tissues, cells, and lysosomes was determined as described by Koster et al. (27). A crude lysosomal fraction was prepared by homogenizing muscle cells in a Potter-Elvejhem homogenizer at $1300 \mathrm{rpm}$ in $250 \mathrm{mM}$ mannitol with $10 \mathrm{mM}$ EDTA and $20 \mathrm{mM}$ imidazol, $\mathrm{pH} 7.4$. Nuclei and intact cells were removed by centrifugation at $100 \times$ $g$. Lysosomes were subsequently spun down from the supernatant at $1000 \times g$ and washed once with homogenization buffer. Protein concentrations were determined according to Lowry et al. (28) and creatine kinase levels were measured as described previously (23). All assays were carried out in duplicate.

Immunocytochemistry was performed according to Van Dongen et al. (29), using mouse monoclonal antibodies (43G8) (30) raised against acid $\alpha$-glucosidase and rabbit polyclonal antibodies against $\beta$-hexosaminidase (31). Immune complexes were visualized with goat anti-mouse IgG conjugated to a green fluorescent dye and goat anti-rabbit IgG conjugated to a red fluorescent dye, respectively.

Glycogen was demonstrated by transmission electron microscopy following the procedure described by De Bruijn (32).

\section{RESULTS}

The clinical diagnosis of infantile glycogenosis type II was confirmed by deficiency of acid $\alpha$-glucosidase activity in leukocytes, cultured skin fibroblasts, and muscle tissue. The same enzyme deficiency was demonstrated in cultured skeletal muscle cells derived from the patient (Table 1). Using immunocytochemistry, enzymatically inactive acid $\alpha$-glucosidase was shown to be absent (Fig. 2A). However, when human urine acid $\alpha$ glucosidase was applied to the deficient cells, a bright intracellular labeling pattern was observed after $16 \mathrm{~h}$ (Fig. $2 B$ ). The distribution of the fluorescent spots suggested compartmentalization in the lysosomes. Indeed, when a double labeling was performed for acid $\alpha$-glucosidase (Fig. 2C) and $\beta$-hexosaminidase (as lyso-
Table 1. Acid $\alpha$-glucosidase activity*

\begin{tabular}{|c|c|c|}
\hline \multirow[b]{2}{*}{ Cells/tissue } & \multicolumn{2}{|r|}{ Substrate } \\
\hline & Glycogen & $\begin{array}{l}\text { 4-methylumbelliferyl- } \\
\alpha \text {-D-glucopyranoside }\end{array}$ \\
\hline \multicolumn{3}{|l|}{ Leukocytes } \\
\hline Patient & 10 & \\
\hline $\begin{array}{l}\text { Control range }(n= \\
10)\end{array}$ & $70-220$ & \\
\hline \multicolumn{3}{|l|}{ Muscle } \\
\hline Patient & 1.1 & 0.54 \\
\hline $\begin{array}{l}\text { Control range ( } n= \\
10 \text { ) }\end{array}$ & $70-350$ & $7-40$ \\
\hline \multicolumn{3}{|l|}{ Cultured fibroblasts } \\
\hline Patient & & 1.1 \\
\hline $\begin{array}{l}\text { Control range }(n= \\
10)\end{array}$ & & $40-150$ \\
\hline \multicolumn{3}{|l|}{ Cultured muscle cells } \\
\hline Patient & & 0.83 \\
\hline $\begin{array}{l}\text { Control range }(n= \\
5 \text { ) }\end{array}$ & & $50-120$ \\
\hline $\begin{array}{l}\text { Patient after en- } \\
\text { zyme uptake }\end{array}$ & & $150-180$ \\
\hline
\end{tabular}

somal marker) (Fig. 2D), exactly the same localization was obtained.

Subsequently, the effect of endocytosed acid $\alpha$-glucosidase on the cellular glycogen content was determined. The experiments were performed with muscle cell cultures consisting of more than $90 \%$ myotubes. The high creatine kinase activity of the cells (1010-1024 $\mathrm{mU} / \mathrm{mg}$ protein) was indicative of their advanced stage of differentiation. Uptake of enzyme, measured after $16 \mathrm{~h}$, had been very efficient. Intracellular activity above the control range was achieved (Table 1; Fig. 3, day 1). The half-life of endocytosed acid $\alpha$-glucosidase varied between 6 and 9 days in different experiments. The effect on the glycogen content of the 

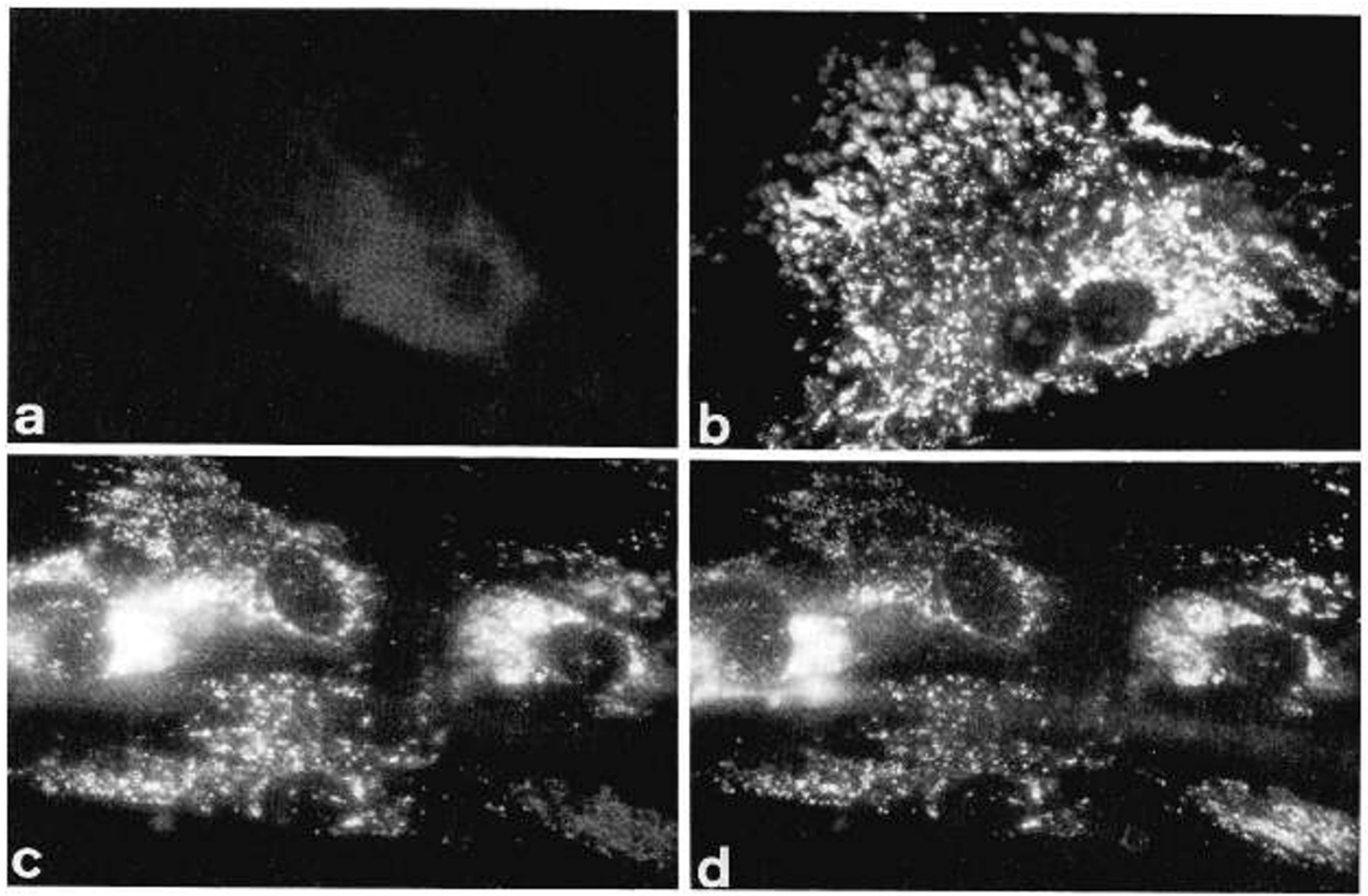

Fig. 2. Immunocytochemical demonstration of acid $\alpha$-glucosidase of cultured muscle cells from the patient: $A$, multinuclear muscle cell before enzyme addition. $b$, binuclear cell $16 \mathrm{~h}$ after enzyme addition. $c$, intracellular localization of acid $\alpha$-glucosidase after endocytosis. $d$, localization of $\beta$-hexosaminidase (as lysosomal marker) in the same cells as in $c$.

cells was most pronounced 6 days after enzyme addition, when the amount of cellular glycogen was approximately $33 \%$ reduced (see Fig. 3 for a representative experiment). In four independent experiments the reduction of cellular glycogen varied from 32$35 \%$. In control cells no degradation of glycogen was measured after acid $\alpha$-glucosidase addition.

Clearance of glycogen was examined by electron microscopy. A striking difference was observed between treated and untreated cultures inspected 6 days after enzyme addition (Fig. 4). Abundant accumulation of glycogen was seen in lysosomes of cells that did not obtain enzyme. In contrast, treated myotubes could not be distinguished from normal. Significant changes in the amount of cytoplasmic glycogen were not observed.

To further substantiate these observations, the distribution of glycogen over cytoplasm and lysosomes was quantitated. In control cells $18-24 \%$ of the total cellular g!ycogen was found in the lysosomal fraction, whereas in cultured muscle cells from the patient the lysosomal glycogen fraction was between 45 and $52 \%$ in various assays. Six days after enzyme addition the lysosomal glycogen content of cells from the patient had returned to control values.

\section{DISCUSSION}

Receptors with different specificities are essential mediators in a variety of cellular and biochemical processes. Two distinct receptors with specificity for the mannose-6-phosphate recognition marker of lysosomal enzymes have been characterized. A $215-\mathrm{kDa}$ cation independent as well as a $46-\mathrm{kDa}$ cation dependent mannose-6-phosphate receptors seem involved in intracellular transport of lysosomal enzymes (33-35). Endocytosis of exogenous lysosomal enzymes seems mainly ascribed to the 215 $\mathrm{kDa}$ receptor (36). Recently, it was shown that the latter receptor

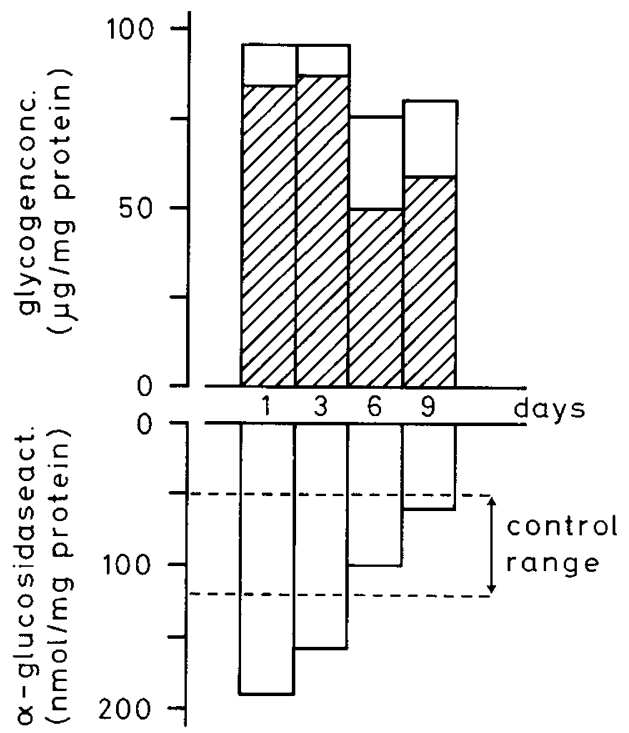

Fig. 3. Acid $\alpha$-glucosidase activity of cultured myotubes after uptake of human urine enzyme (open bars downward). Cellular glycogen content without (open bars upward) and after enzyme addition (hatched bars). Assays of enzyme activity and glycogen content were carried out in duplicate wells. The average values of the duplicate experiments are indicated. The variation between duplicates was less than $4 \%$.

is identical to the IGF II receptor (37). The exact physiological function of the mannose-6-phosphate receptor as IGF II receptor is not yet understood. IGF II seems to function primarily in fetal and early neonatal development. 


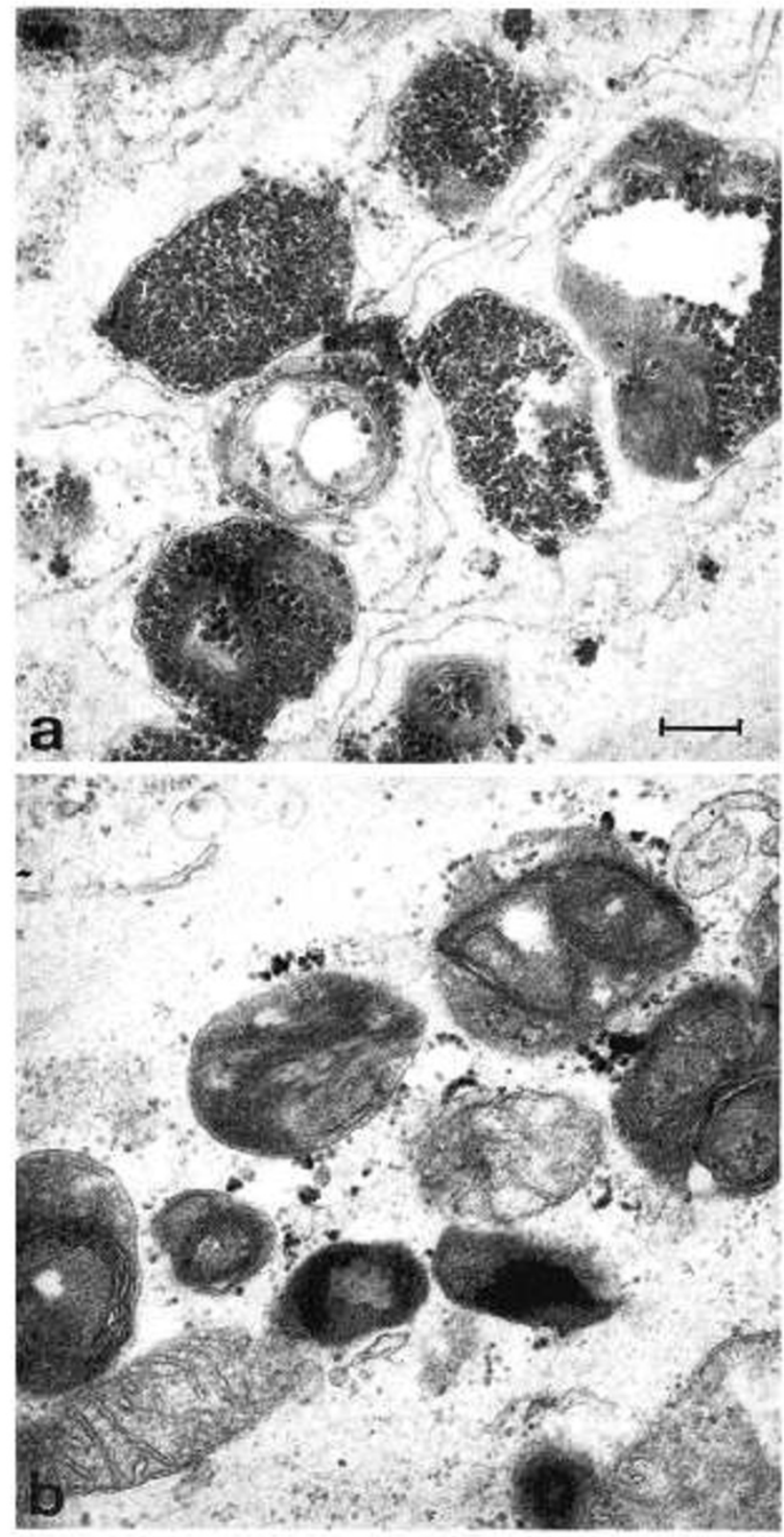

Fig. 4. Transmission electron micrographs: $A$, cultured muscle cells from the patient; $B$, a duplicate culture 6 days after treatment with human urine acid $\alpha$-glucosidase. Bar, $2.5 \mu \mathrm{m}$.

Mannose-6-phosphate receptors are transiently present on the plasma membrane of a variety of cell types $(17-19,33,38)$. We have previously shown that mannose-6-phosphate receptors on the surface of skeletal muscle cells can be used as targets for acid $\alpha$-glucosidase species with a high mannose-6-phosphate content (21). The precursor of acid $\alpha$-glucosidase, which is rather abundant in urine, has this desired characteristic $(24,39)$, and was used in our study as the enzyme source. After uptake by muscle cells the precursor was converted to fully active mature enzyme. This is concluded from the fact that endocytosed acid $\alpha$-glucosidase can be visualized with monoclonal antibody $43 \mathrm{G} 8$, that only recognizes mature enzyme, and not the administered precursor $(30,40)$. In addition, the immunocytochemical labeling pattern demonstrates that all lysosomes are reached, and not a selected subset. Uptake of enzyme appeared very efficient. Activities above the control range were reached. Nine days after correction, the acid $\alpha$-glucosidase activity was still at the lower limit of the control range. Clearance of glycogen from lysosomes, as assessed by transmission electron microscopy and quantitative assays, demonstrates that exogenously supplied acid $\alpha$-glucosidase can functionally replace deficient endogenous enzyme. Our results suggest that the reported degradation of glycogen in cultured bovine muscle cells after enzyme addition also occurs in lysosomes (41). Thus, receptor-mediated enzyme replacement therapy for glycogenosis type II may be feasible, if high uptake forms of acid $\alpha$-glucosidase would gain sufficient access to affected muscle tissue.

In the past, results obtained with administration of enzyme to patients with lysosomal storage disorders, and to animals, have been disappointing (7-10). Enzymes administered parenterally appeared to be captured predominantly by the Kupffer cells of the liver (42), and the initial enthusiasm about the applicability of enzyme replacement therapy subsided. However, with the present knowledge about low and high uptake forms of lysosomal enzymes and the occurrence of cell type-specific receptors (8, $17-19,21,33-39)$ it has to be concluded that in these trials the optimal conditions for enzyme replacement therapy were not used. In retrospect, the wrong species of acid $\alpha$-glucosidase were administered in attempts to correct glycogenosis type II $(4,9$, $10)$. Acid $\alpha$-glucosidase purified from human placenta does not contain mannose-6-phosphate residues and is very poorly taken up by cultured muscle cells $(21,43)$. In contrast, mannose-6phosphate-containing enzyme from urine is rapidly endocytosed by muscle cells. By supplying high uptake forms of acid $\alpha$ glucosidase muscle cells may compete with macrophages for enzyme capture (38).

At present, the possibilities of bone marrow transplantation and cell and tissue transplantation are being explored (11-16, 44-47). The effectiveness of these procedures depends on transfer of donor enzyme to the affected organs and cell types. Our data also predict that these latter forms of therapy will be more efficient when the transplanted cells supply high-uptake forms of acid $\alpha$-glucosidase to deficient muscle.

We have shown that cultured skeletal muscle from patients with glycogenosis type II is a suitable model system for fundamental studies on enzyme supplementation. Studies on animal models are in progress to test the in vivo feasibility of enzyme replacement therapy by infusion of high uptake forms of acid $\alpha$ glucosidase. An important question will be whether the enzyme can cross the capillary wall to reach its ultimate goal. Suggestive evidence exists that various macromolecules are actively transported across endothelial cells via plasmalemmal vesicles (48$50)$.

Acknowledgments. The authors thank Dr. J. M. Tager for his generous gift of monoclonal antibody 43G8, M. Witsenburg and E. E. M. van Essen Zandvliet for referring the patient, W. J. Visser for electronmicroscopy, $\Upsilon$. van Os for photography, and D. Heinsius for secretarial assistance.

\section{REFERENCES}

1. Pompe JC 1932 Over ideopatische hypertrophie van het hart. Ned Tijdschr Geneesk 76:304-311

2. Howell RR, Williams JC 1983 The glycogen storage diseases. In: Stanburry JB, Wijngaarden JB, Fredrickson DS, Goldstein JL, Brown MS (eds) The Metabolic Basis of Inherited Diseases, 5th ed. McGraw-Hill, New York, pp $141-166$

3. Hers HG $1963 \alpha$-Glucosidase deficiency in generalized glycogen storage disease (Pompe's disease). Biochem J 86:11-16

4. Hers HG, De Barsy Th 1973 Type II glycogenosis (acid maltase deficiency). In: Hers HG, Van Hoof F (eds) Lysosomes and Storage Diseases. Academic Press, New York, pp 197-216

5. Trend P StJ, Wiles CM, Spencer GT, Morgan-Hughes JA, Lake BD, Patrick AD 1985 Acid maltase deficiency in adults. Diagnosis and management in five cases. Brain 108:845-860

6. Loonen MCB, Busch HFM, Koster JF, Martin JJ, Niermeijer MF, Schram AW, Brouwer-Kelder B, Mekes W, Slee RG, Tager JM 1981 A family with different clinical forms of acid maltase deficiency (glycogenosis type II): biochemical and genetic studies. Neurology 31:1209-1216

7. Tager JM, Hooghwinkel GJM, Daems WTh (eds) 1974 Enzyme Therapy in 
Lysosomal Storage Diseases. North-Holland Publishing Company, Amsterdam

8. Desnick RJ (ed) 1980 Enzyme Therapy in Genetic Diseases: 2. Alan R. Liss, New York

9. Hug G, Schubert WK 1967 Lysosomes in type II glycogenosis. Changes during administration of extract from Aspergillus niger. J Cell Biol 35:C1-C6

10. Baudhuin P, Hers HG, Loeb H 1964 An electron microscopic and biochemical study of type II glycogenosis. Lab Invest 13:1139-1152

11. Barranger JA 1984 Marrow transplantation in genetic disease. N Engl J Med 311:1629-1631

12. Parkman R 1986 The application of bone marrow transplantation to the treatment of genetic diseases. Science 232:1373-1378

13. Krivit W, Whitley $\mathrm{CB} 1986$ Bone marrow transplantation for genetic diseases. N Engl J Med 316:1085-1087

14. Krivit W, Paul NW 1986 Bone Marrow Transplantation for Treatment of Lysosomal Storage Diseases. Alan R Liss, New York

15. Harris RE, Hannon D, Vogler C, Hug G 1986 Bone marrow transplantation in type Ila glycogen storage disease. In: Krivit W, Paul NW (eds) Bone Marrow Transplantation for Treatment of Lysosomal Storage Diseases. Alan R Liss, New York, pp 119-132

16. Watson GJ, Gardner-Medwin D, Goldfinch ME, Pearson ADJ 1986 Bone marrow transplantation for glycogen storage disease type II (Pompe's disease). N Engl J Med 314:385

17. Kaplan A, Achord DT, Sly WS 1977 Phosphohexosyl components of a lysosomal enzyme are recognized by pinocytosis receptors on human fibroblasts. Proc Natl Acad Sci USA 74:2026-2030

18. Sando GN, Neufeld EF 1977 Recognition and receptor-mediated uptake of a lysosomal enzyme, $\alpha$-L-iduronidase, by cultured human fibroblasts. Cell 12:619-627

19. Creek KE, Sly WS 1984 The role of the phosphomannosyl receptor in the transport of acid hydrolases to lysosomes. In: Dingle JT, Dean RT, Sly W (eds) Lysosomes in Biology and Pathology. Elsevier, Amsterdam, pp 63-82

20. Fischer HD, Gonzalez-Noriega A, Sly WS, Morre DJ 1980 Phosphomannosylenzyme receptors in rat liver. Subcellular distribution and role in intracellular transport of lysosomal enzymes. J Biol Chem 255:9608-9615

21. Reuser AJJ, Kroos MA, Ponne NJ, Wolterman RA, Loonen MCB, Busch HFM, Visser WJ, Bolhuis PA 1984 Uptake and stability of human and bovine acid $\alpha$-glucosidase in cultured fibroblasts and skeletal muscle cells from glycogenosis type II patients. Exp Cell Res 155:178-189

22. Yasin R, Van Beers G, Nurse KCE, Ali-Ani S, Landon DN, Thompson EJ 1977 A quantitative technique for growing human adult skeletal muscle in culture starting from mononucleated cells. J Neurol Sci 32:347-360

23. Bolhuis PA, De Zwart HJD, Ponne NJ, De Jong JMBV 1985 Free-energy carriers in cultured muscle cells. Muscle Nerve 8:22-26

24. Oude Elferink RPJ, Brouwer-Kelder EM, Surya I, Strijland A, Kroos M, Reuser AJJ, Tager JM 1984 Isolation and characterization of a precursor form of lysosomal $\alpha$-glucosidase from human urine. Eur J Biochem 139:489495

25. Galjaard H 1980 Genetic Metabolic Diseases: Early Diagnosis and Prenatal Analysis. Elsevier/North Holland, Amsterdam, pp 809-827

26. Reuser AJJ, Koster JF, Hoogeveen A, Galjaard H 1978 Biochemical, immu nological and cell genetic studies in glycogenosis type II. Am J Hum Genet 30:132-143

27. Koster JF, Slee RG, Hulsman WC 1972 The use of leucocytes as an aid in the diagnosis of a variant of glycogen storage disease type II (Pompe's disease). Eur J Clin Invest 2:467-471

28. Lowry OH, Rosebrough NJ, Farr AL, Randall RJ 1951 Protein measurement with folin phenol reagent. J Biol Chem 193:265-275

29. Van Dongen JM, Barneveld RA, Geuze HJ, Galjaard H 1984 Immunocytochemistry of lysosomal hydrolases and their precursor forms in normal and mutant human cells. Histochem J 16:941-954
30. Oude Elferink RPJ, Strijland A, Surya I, Brouwer-Kelder EM, Kroos M, Hilkens J, Hilgers J, Reuser AJJ, Tager.JM 1984 Use of a monoclonal antibody to distinguish between precursor and mature forms of human lysosomal $\alpha$-glucosidase. Eur J Biochem 139:497-502

31. Reuser AJJ, Kroos M, Oude Elferink RPJ, Tager JM 1985 Defects in synthesis, phosphorylation, and maturation of acid $\alpha$-glucosidase in glycogenosis type II. J Biol Chem 260:8336-8341

32. De Bruijn WC 1973 Glycogen, its chemistry and morphologic appearance in the electron microscope. A modified $\mathrm{OsO}_{4}$ fixative, which selectively contrasts glycogen. J Ultrastruct Res 42:29-50

33. Sahagian GG, Distler J, Jourdian GW 1981 Characterization of a membraneassociated receptor from bovine liver that binds phosphomannosyl residues of bovine testicular $\beta$-galactosidase. Proc Natl Acad Sci USA 78:4289-4293

34. Lobel P, Dahms NM, Breitmeyer J, Chirgwin JM, Kornfeld S 1987 Cloning of the bovine $215 \mathrm{kDa}$ cation-independent mannose 6-phosphate receptor. Proc Natl Acad Sci USA 84:2233-2237

35. Dahms NM, Lobel P, Breitmeyer J, Chirgwin JM, Kornfeld S 198746 kd Mannose 6-phosphate receptor: cloning, expression, and homology to the $215 \mathrm{kd}$ mannose 6-phosphate receptor. Cell 50:181-192

36. Stein M, Zijderhand-Bleekemolen JE, Geuze H, Haselik A, Von Figura K 1987 $\mathrm{M}_{\mathrm{r}} 46000$ mannose 6-phosphate specific receptor: its role in targeting of lysosomal enzymes. EMBO J 6:2677-2681

37. Morgan DO, Edman JC, Standring DN, Fried VA, Smith MC, Roth RA, Rutter WJ 1987 Insulin-like growth factor II receptor as a multifunctiona binding protein. Nature 329:301-307

38. Shepherd VL, Stahl PD 1984 Macrophage receptors for lysosomal enzymes. In: Dingle JT, Dean RT, Sly W (eds) Lysosomes in Biology and Pathology. Elsevier, Amsterdam, pp 83-98

39. Shapiro LJ, Hall CW, Leder IG, Neufeld EF 1976 The relationship of $\alpha$-L iduronidase and Hurler corrective factor. Arch Biochem Biophys 172:156161

40. Oude Elferink RPJ, Van Doorn-Van Wakeren J, Hendriks T, Strijland A Tager JM 1986 Transport and processing of endocytosed lysosomal $\alpha$ glucosidase in cultured human skin fibroblasts. Eur J Biochem 158:339-344

41. DiMarco PN, Howell JMcC, Dorling PR 1985 Bovine generalised glycogenosis type II. Uptake of lysosomal $\alpha$-glucosidase by cultured skeletal muscle and reversal of glycogen accumulation. FEBS Lett 190:301-304

42. Achord DT, Brot FE, Sly WS 1977 Inhibition of the rat clearance system for agalacto-orosomucoid by yeast mannans and by mannose. Biochem Biophys Res Commun 77:409-415

43. Mutsaers JHGM, Van Halbeek H, Vliegenthart JFG, Tager JM, Reuser AJJ, Kroos M, Galjaard H 1987 Determination of the structure of the carbohydrate chains of acid $\alpha$-glucosidase from human placenta. Biochim Biophys Acta 911:244-251

44. Hoogerbrugge PM, Wagemaker G, Van Bekkum DW, Reuser AJJ, Van Der Ploeg AT 1986 Bone marrow transplantation for Pompe's disease. N Engl J Med 315:65-66

45. Hug G 1986 More on bone marrow transplantation for glycogen storage disease type II (Pompe's disease). N Engl J Med 315:1229

46. Watson JG, Gardner Medwin FRCP, Pearson ADJ 1986 More on bone marrow transplantation for glycogen storage disease type II (Pompe's disease). $\mathrm{N} \mathrm{Engl}$ J Med 315:1229

47. Selden RF, Skoskiewicz MJ, Burke Howie K, Russell PS, Goodman HM 1987 Implantation of genetically engineered fibroblasts into mice: implications for gene therapy. Science 236:714-718

48. Bruns RR, Palade GE 1968 Studies on blood capillaries II. Transport of ferritin molecules across the wall of muscle capillaries. J Cell Biol 37:277-299

49. Simionescu N, Simionescu M, Palade GE 1973 Permeability of muscle capillaries to exogenous myoglobin. J Cell Biol 57:424-452

50. Milici AJ, Watrous NE, Stukenbrok H, Palade GE 1987 Transcytosis of albumin in capillary endothelium. J Cell Biol 105:2603-2612 